\title{
FORECASTING THE PROPERTIES OF LINEAR BLOCK-COPOLIURETHANES BASED ON OLIGOESTERS OF REGULAR STRUCTURE
}

\author{
Ukrainian State University of Chemical Technology, Dnipro, Ukraine
}

\begin{abstract}
We showed that the development of recommendations for a reasonable choice of linear block copolyurethanes that would be optimal for given operating conditions is still intuitive and does not consider the features of the molecular structure and the nature of initial components. We suggested a new scientifically grounded approach to the creation of linear block-copolyurethanes with increased wear resistance in relation to strength, deformation, thermophysical and tribotechnical characteristics. To simplify analysis of the properties of the studied materials, a mathematical model was developed, which describes the relationship between all considered properties of materials and their structure. We proposed to assess the relationship between structure and properties of the investigated materials by using quality indexes. Maximum values of quality indexes, depending on the operating conditions, correspond to different contents of hard blocks $\left(\mathrm{P}_{\mathrm{c}}\right)$, and, consequently, to different molecular structure of the studied polyurethanes. Thus, it is reasonable to use block-copolyurethanes based on $\mathrm{OBGA}_{500}$ with a maximum content of hard blocks $\left(\mathrm{P}_{\mathrm{c}}>60 \%\right)$ for operating conditions where it is necessary to provide high strength characteristics. Polyurethanes synthesized with the formation of clusters of hard blocks in the range of $45-55 \%$ are recommended for the use as wear-resistant materials.
\end{abstract}

Keywords: linear block-copolyurethane, oligoester, physical and mechanical characteristics, wear intensity, material quality index.

DOI: $10.32434 / 0321-4095-2021-137-4-4-10$

\section{Introduction}

It is known that polyurethanes are universal and widespread polymers. This is due to the wide possibilities of changing their chemical composition, structure and properties [1]. Polyblock-polyurethanes of linear structure attract particular attention. They have a successful combination of properties: high strength combined with elasticity, satisfactory oil and gas resistance, resistance to shock loads and vibrations [2]. The experience of using these materials, including $3 \mathrm{D}$ prototyping methods, has been accumulated in all industries without exception [3,4]. However, the development of practical recommendations related to the justification of the choice of blockcopolyurethanes (BPU), optimal for specific operating conditions, is mainly intuitive. Therefore, the studies of relationship between the structure of linear block-copolyurethanes and strength, deformation, thermophysical and tribological characteristics as well as mathematical prediction of their behavior under different operating conditions, taking into account the quality indicators of the material, are of great practical importance for the use in industry.

\section{Experimental}

Linear block-copolyurethanes of various morphologies were studied in this work. We used the esters of a regular structure: oligobutylene glycol adipate with a molecular weight of $\sim 500\left(\mathrm{OBGA}_{500}\right)$. Urethane groups were formed from 4,4'diphenylmethane diisocyanate (MDI). To create a block structure of BPU, a low molecular weight glycol ( 1,4 butanediol, butylene glycol, BD) was introduced $[5,6]$.

The main characteristics of the initial components used for the synthesis of polyurethane block-copolymers (BPU $\mathrm{OBGA}_{500}$ ) are given in Table 1.

The samples were obtained under laboratory conditions by a one-stage synthesis in mass at the molar ratio of $\mathrm{NCO}: \mathrm{OH}=1.0: 1.0$.

The morphological structure was varied by changing the ratio of butanediol to oligoester during synthesis. With an increase in the amount of butanediol, an increase in the content of rigid blocks 
Table 1

Initial components that are used for the synthesis of block-copolyurethanes BPU OBGA ${ }_{500}[5,6]$

\begin{tabular}{|c|c|c|c|c|c|}
\hline Component & $\begin{array}{c}\text { Abbreviated } \\
\text { designation }\end{array}$ & $\begin{array}{l}\text { Average } \\
\text { molecular } \\
\text { weight }\end{array}$ & Purpose & Chemical formula & Characteristics \\
\hline $\begin{array}{l}\text { Oligobutylene } \\
\text { glycol adipate }\end{array}$ & $\mathrm{OBGA}_{500}$ & $\approx 500$ & oligoester & $\mathrm{HO}\left[-\mathrm{CO}\left(\mathrm{CH}_{2}\right)_{4}-\mathrm{COO}\left(\mathrm{CH}_{2}\right)_{4} \mathrm{O}-\right]_{\mathrm{n}} \mathrm{H}$ & $\begin{array}{l}\mathrm{T}_{\mathrm{m}}=19.9^{0} \mathrm{C} \text {, mass fraction } \\
\text { of hydroxyl groups is } \\
1.6-1.9 \% \text {, acid number is } \\
1.3 \mathrm{mg} \mathrm{KOH} / \mathrm{g}\end{array}$ \\
\hline $\begin{array}{l}\text { 4,4-methylene } \\
\text { diphenyl } \\
\text { diisocyanate }\end{array}$ & MDI & 250 & isocyanate & $\mathrm{OCN}-\mathrm{C}_{6} \mathrm{H}_{4}-\mathrm{CH}_{2}-\mathrm{C}_{6} \mathrm{H}_{4}-\mathrm{NCO}$ & $\begin{array}{l}T_{m}=39^{0} \mathrm{C}, T_{b}=157^{0} \mathrm{C}, \\
\rho=1190 \mathrm{~kg} / \mathrm{m}^{3}\end{array}$ \\
\hline $\begin{array}{l}\text { 1,4-butanediol } \\
\text { (butylene glycol) }\end{array}$ & $\mathrm{BD}$ & 90 & $\begin{array}{c}\text { chain } \\
\text { extension }\end{array}$ & $\mathrm{HO}-\left(\mathrm{CH}_{2}\right)_{4}-\mathrm{OH}$ & $\mathrm{T}_{\mathrm{m}}=30^{0} \mathrm{C}, \mathrm{T}_{\mathrm{b}}=203^{0} \mathrm{C}$ \\
\hline
\end{tabular}

$\left(\mathrm{P}_{c}\right)$ in block-copolyurethanes is observed, which was determined as a part of a molecule with a low molecular weight diol according to the following expression:

$$
\mathrm{P}_{\mathrm{c}}=\frac{90 \mathrm{n}+250(\mathrm{n}+1)}{\mathrm{aM}_{\mathrm{oe}}+90 \mathrm{n}+250(\mathrm{n}+1)} 100 \%
$$

where $\mathrm{P}_{\mathrm{c}}$ is the content of hard blocks (\%); $\mathrm{M}_{\mathrm{oe}}$ is the molecular weight of oligoester (500); 90 stands for the molecular weight of butanediol; 250 stands for the molecular weight of diisocyanate; $a$ is the number of moles of oligoester; $n$ is the number of moles of butanediol; and $(n+1)$ is the number of moles of diisocyanate.

Polyurethane block-copolymers with a content of hard blocks $\left(\mathrm{P}_{\mathrm{c}}\right)$ in the range from $33 \%$ to $72 \%$ were investigated, this allowed studying polymers with a wide range of properties.

Experimental results were obtained using standard methods of physical-mechanical tests, $\mathrm{X}$-ray structural and thermomechanical analyzes as well as special methods for studying the processes of friction and wear of BPU in the absence of lubrication, water, and in the flow of abrasive particles [7].

\section{Results and discussion}

To create materials with preset complex of properties, it is necessary to conduct a large number of experiments and analyze the results. The more experimental studies are conducted, the more accurate the recommendations can be given. Thus, to create polymeric materials based on blockcopolyurethanes with enhanced wear resistance, it is necessary, at least, to trace the relationship between their structure and strength, deformation, thermophysical and tribological characteristics.

As an example, Table 2 presents the results of determining the physical-mechanical characteristics of polyurethane block-copolymers based on oligoesters of a regular structure (BPU OBGA $\left.{ }_{500}\right)$.

As follows from Table 2, the residual elongation (ع) of polyurethane block-copolymers increases rapidly with increasing the amount of butanediol and, accordingly, the content of hard blocks. The same rapid growth is observed for elastic modulus $\left(E_{p}\right)$, hardness $\left(H_{A}\right)$, Vicat softening temperature $\left(T_{p}\right)$ and degree of crystallinity $\left(\mathrm{S}_{\mathrm{k}}\right)$. The relative elongation $\left(\varepsilon_{\mathrm{p}}\right)$ decreases with an increase in the content of rigid blocks. The dependence of $\varepsilon_{\mathrm{p}}$ on $\mathrm{P}_{\mathrm{c}}$ has an S-like character: there are two inflection points at $\mathrm{P}_{\mathrm{c}}=46 \%$ and $\mathrm{P}_{\mathrm{c}}=54 \%$. The conditional tensile strength $\left(f_{\mathrm{p}}\right)$ vs. $\mathrm{P}_{\mathrm{c}}$ dependence has an extreme character with a minimum in the range $\mathrm{P}_{\mathrm{c}}=46-54 \%$. Tribological characteristics under friction conditions without lubrication and friction in water have similar views, and the value of gas abrasive wear intensity has a plateau in the range $\mathrm{P}_{\mathrm{c}}=46-54 \%$.

Tabular and graphical representation of the whole results concerning the BPU research is difficult, although it gives the most complete information about their properties. In addition, these methods of representation provide low accuracy of results and lead to a large number of errors due to the human factor, which is unacceptable.

To simplify analysis of the properties of the studied materials, a mathematical model was developed, which describes the relationship between the mentioned properties of materials and their structure.

The described system is a set of functions of one argument, $\mathrm{P}_{\mathrm{c}}$. Functions are given graphically. After approximating any individual dependence, we obtained a set of regression equations that allow describing the relationship between all the characteristics of the studied BPU and thus predicting the probable possibility of their application in specific production conditions.

Input data are entered in the form of column 
Physical-mechanical characteristics of block-copolyurethanes based on $\mathrm{OBGA}_{500}$ :BD:MDI

Table 2 of various morphological structure

\begin{tabular}{|c|c|c|c|c|c|c|c|c|c|c|c|c|c|}
\hline 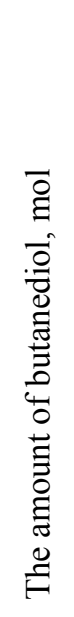 & $\begin{array}{l}0 \\
0 \\
0 \\
0 \\
0 \\
0 \\
0 \\
0 \\
0 \\
0 \\
\overline{0} \\
4 \\
0 \\
0 \\
0 \\
0 \\
0\end{array}$ & 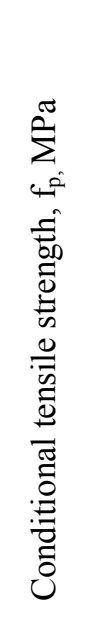 & 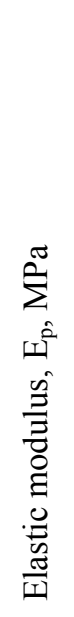 & 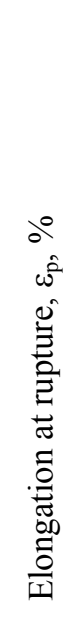 & 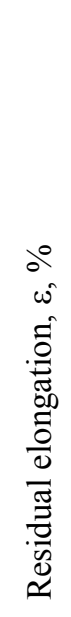 & 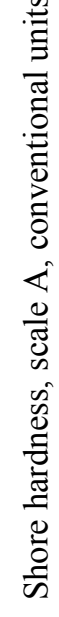 & 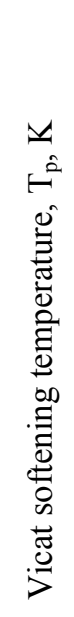 & 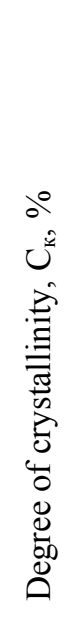 & 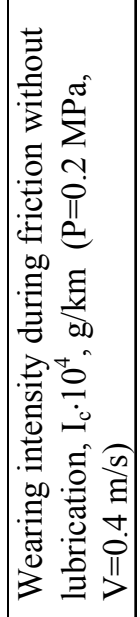 & 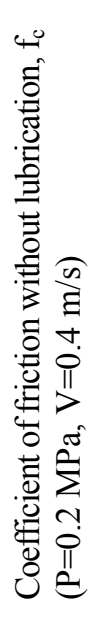 & 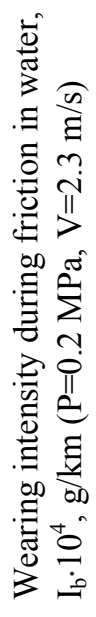 & 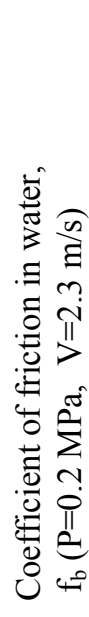 & 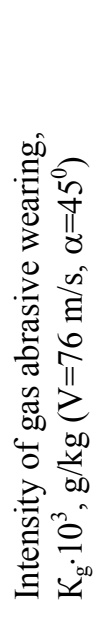 \\
\hline 0 & 33 & 63 & 15 & 500 & 5 & 87 & 321 & $\sim 0$ & 18 & 2 & 33 & 0.8 & - \\
\hline 0.5 & 46 & 61 & 95 & 470 & 28 & 96 & 323 & $\sim 0$ & 2.5 & 1.2 & 24 & 0.35 & 8 \\
\hline 1 & 54 & 61.5 & 180 & 370 & 90 & 97 & 463 & 3.4 & 3.5 & 0.95 & 18 & 0.3 & 15 \\
\hline 1.5 & 60 & 62 & 650 & 360 & 150 & 98 & 450 & 6.5 & 4 & 1 & 19 & 0.33 & 30 \\
\hline 2 & 65 & 63 & 820 & 350 & 235 & 99 & 463 & 7.4 & 4.5 & 1.05 & 20 & 0.36 & 45 \\
\hline 2.5 & 69 & 63.5 & - & 350 & 280 & 99 & 488 & 6.5 & 5 & 1.1 & 21 & 0.39 & 62 \\
\hline 3 & 72 & 64 & - & 350 & 300 & 99 & 490 & 4.3 & 5.5 & 1.15 & 22 & 0.4 & 80 \\
\hline
\end{tabular}

vectors; variables are marked with the lower index «exp»; the index «exp» is discarded after the transition to approximating functions.

The «linfit» function of Mathcad package is used to approximate each individual function. Figure 1 shows a fragment of the Mathcad document, which approximates the dependence of intensity of wear during friction without lubrication on the content of hard blocks $I_{c}\left(P_{c}\right)$.

The variables $P_{\text {c.exp }}$ and $1_{\text {c.exp }}$ in Fig. 1 are designated as $\mathrm{X}$ and $\mathrm{Y}$, respectively. This operation is performed to unify the core of the approximation unit, which includes calculating the vector of the coefficients a of the regression equation using the functions $S(X)$ and linfit $(X, Y, S(X))$ and creating the form of the regression equation by function $\mathrm{y}(\mathrm{x})$. After that, the results of the block core are recoded into a more perceptible form and displayed on the screen as a regression equation. Coefficients with very small numerical values are not discarded,

$$
\begin{aligned}
& P_{c}:=P_{c} \\
& X:=P_{c \cdot e x p} \quad Y:=I_{c} \exp \quad S(X):=\left(1 \times x^{2} x^{3} x^{4} x^{5} x^{6}\right)^{T} \quad a:=\operatorname{linfit}(X, Y, S)=\left(\begin{array}{c}
5.251 \times 10^{-5} \\
4.485 \times 10^{-4} \\
-2.613 \times 10^{-5} \\
4.669 \times 10^{-7} \\
-5.162 \times 10^{-10} \\
-5(x):=a_{7} \cdot x^{6}+a_{6} \cdot x^{5}+a_{5} \cdot x^{4}+a_{4} \cdot x^{3}+a_{3} \cdot x^{2}+a_{2} \cdot x+a_{1} \\
I_{c}\left(P_{c}\right):=y\left(P_{c}\right) \\
I_{c}\left(P_{c}\right) \text { float }, 3 \rightarrow 0.182 \times 10^{-13}
\end{array}\right)
\end{aligned}
$$

Fig. 1. Mathcad block for approximation of the function $I_{c}\left(P_{c}\right)$ 
because they, as usual, stand at members of a polynomial with high exponents and significantly affect the accuracy of the approximation.

The results of the approximation of the function $I_{c}\left(P_{c}\right)$ are presented graphically in Fig. 2.

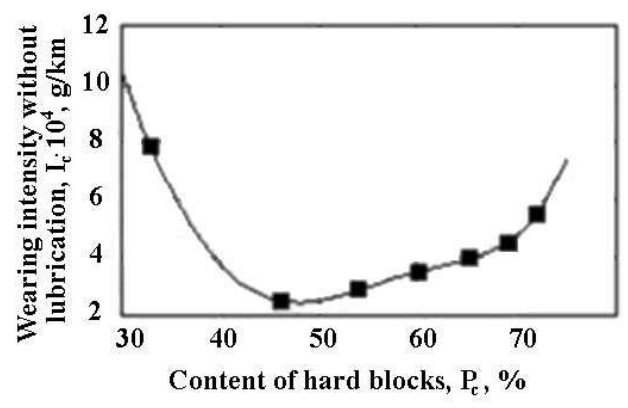

Fig. 2. Results of function approximation $\mathrm{I}_{\mathrm{c}}\left(\mathrm{P}_{\mathrm{c}}\right)(\mathrm{P}=0.2 \mathrm{MPa}$,

$$
\mathrm{V}=0.4 \mathrm{~m} / \mathrm{s})
$$

For each individual function, the optimal degree of a polynomial can vary depending on the complexity of its behavior. Whenever possible, polynomials of lower degrees are used. Taking into account that the number of experimental points is 7 , the greatest appropriate degree of the polynomial is 6 , in which the curve accurately passes through all the experimental points. The use of approximating functions of another type (not polynomial) is also not appropriate in this case, because then there are additional limitations on the method of solving the basic system of equations.

After approximating all the curves, we obtain the following system of algebraic equations (2):

$$
\begin{aligned}
& \mathrm{f}_{\mathrm{p}}\left(\mathrm{P}_{\mathrm{c}}\right)=-7.74 \cdot 10^{-5} \cdot \mathrm{P}_{\mathrm{c}}^{3}+0.0166 \mathrm{P}_{\mathrm{c}}{ }^{2}-1.03 \mathrm{P}_{\mathrm{c}}+80.5 ; \\
& \mathrm{E}_{\mathrm{p}}\left(\mathrm{P}_{\mathrm{c}}\right)=-0.0164 \mathrm{P}_{\mathrm{c}}^{3}-1.25 \mathrm{P}_{\mathrm{c}}^{2}+23.8 \mathrm{P}_{\mathrm{c}}+6.21 \text {; } \\
& \varepsilon_{\mathrm{p}}\left(\mathrm{P}_{\mathrm{c}}\right)=-4,55 \cdot 10^{-4} \cdot \mathrm{P}_{\mathrm{c}}^{4}+0.103 \mathrm{P}_{\mathrm{c}}^{3}-8,49 \mathrm{P}_{\mathrm{c}}{ }^{2}+ \\
& +294 \mathrm{P}_{\mathrm{c}}-3133 \text {; } \\
& \varepsilon\left(\mathrm{P}_{\mathrm{c}}\right)=-5.62 \mathrm{P}_{\mathrm{c}}^{4}+0.115 \mathrm{P}_{\mathrm{c}}{ }^{3}-8.32 \mathrm{P}_{\mathrm{c}}{ }^{2}+260 \mathrm{P}_{\mathrm{c}}-2962 ; \\
& \mathrm{H}_{\mathrm{A}}\left(\mathrm{P}_{\mathrm{c}}\right)=2.4 \cdot 10^{-3} \cdot \mathrm{P}_{\mathrm{c}}{ }^{4}-5.24 \cdot 10^{-3} \cdot \mathrm{P}_{\mathrm{c}}^{3}+0.412 \mathrm{P}_{\mathrm{c}}{ }^{2}- \\
& -13.4 \mathrm{P}_{\mathrm{c}}+240 \text {; } \\
& \mathrm{T}_{\mathrm{A}}\left(\mathrm{P}_{\mathrm{c}}\right)=-7.59 \cdot 10^{-8} \cdot \mathrm{P}_{\mathrm{c}}^{6}+2.79 \cdot \mathrm{P}_{\mathrm{c}}^{5}-3.9 \cdot 10^{-3} \cdot \mathrm{P}_{\mathrm{c}}^{4}+ \\
& +0.259 \mathrm{P}_{\mathrm{c}}^{3}-8.15 \mathrm{P}_{\mathrm{c}}^{2}-97.4 \mathrm{P}_{\mathrm{c}}+11.4 \text {; } \\
& \mathrm{C}_{\mathrm{k}}\left(\mathrm{P}_{\mathrm{c}}\right)=2.68 \cdot 10^{-8} \cdot \mathrm{P}_{\mathrm{c}}^{6}-7.25 \cdot 10^{-4} \cdot \mathrm{P}_{\mathrm{c}}^{5}+7.56 \cdot 10^{-4} \cdot \mathrm{P}_{\mathrm{c}}^{4}- \\
& -0.0378 \mathrm{P}_{\mathrm{c}}^{3}+0.906 \mathrm{P}_{\mathrm{c}}^{2}-8.35 \mathrm{P}_{\mathrm{c}}-0.98 \text {; } \\
& \mathrm{f}_{\mathrm{c}}\left(\mathrm{P}_{\mathrm{c}}\right)=-8.26 \cdot 10^{-6} \cdot \mathrm{P}_{\mathrm{c}}^{3}-2.32 \cdot 10^{-3} \cdot \mathrm{P}_{\mathrm{c}}{ }^{2}-0.196 \mathrm{P}_{\mathrm{c}}+6.21 \text {; } \\
& \mathrm{I}_{\mathrm{c}}\left(\mathrm{P}_{\mathrm{c}}\right)=4.18 \cdot 10^{-13} \cdot \mathrm{P}_{\mathrm{c}}^{6}-5.94 \cdot 10^{-11} \cdot \mathrm{P}_{\mathrm{c}}^{5}-5.16 \cdot 10^{-10} \cdot \mathrm{P}_{\mathrm{c}}^{4}+ \\
& +4.67 \cdot 10^{-7} \cdot \mathrm{P}_{\mathrm{c}}^{3}-2.61 \cdot 10^{-5} \cdot \mathrm{P}_{\mathrm{c}}^{2}+4.49 \cdot 10^{-4} \cdot \mathrm{P}_{\mathrm{c}}+5.25 \cdot 10^{-5} \text {; } \\
& \mathrm{f}_{\mathrm{b}}\left(\mathrm{P}_{\mathrm{c}}\right)=-1.85 \cdot 10^{-9} \cdot \mathrm{P}_{\mathrm{c}}^{6}+5.61 \cdot 10^{-7} \cdot \mathrm{P}_{\mathrm{c}}^{5}-6.75 \cdot 10^{-5} \cdot \mathrm{P}_{\mathrm{c}}^{4}+ \\
& +4.04 \cdot 10^{-3} \cdot \mathrm{P}_{\mathrm{c}}^{3}-0.12 \mathrm{P}_{\mathrm{c}}^{2}+1.41 \mathrm{P}_{\mathrm{c}}+0.166 \text {; } \\
& \mathrm{I}_{\mathrm{b}}\left(\mathrm{P}_{\mathrm{c}}\right)=-4.69 \cdot 10^{-8} \cdot \mathrm{P}_{\mathrm{c}}^{3}+9.48 \cdot 10^{-6} \cdot \mathrm{P}_{\mathrm{c}}^{2}-6.16 \mathrm{P}_{\mathrm{c}}-0.0149 \text {; }
\end{aligned}
$$

where $\mathrm{Kg}_{15}, \mathrm{Kg}_{30}, \mathrm{Kg}_{45}, \mathrm{Kg}_{60}, \mathrm{Kg}_{90}$ are the abrasive wear at the angles of attack of $15^{\circ}, 30^{\circ}, 45^{\circ}, 65^{\circ}$, and $90^{\circ}$, respectively.

Due to the origin of equations of this system (data approximation), only two variables occur simultaneously in each equation. The total number of equations is 16. The total number of variables is 17 , that is why in this state the system does not have a single solution.

Boundary conditions (initial and final) which are imposed on the system are shown in (3):

$$
\begin{array}{ll}
\mathrm{P}_{\mathrm{c}}=33 . .72 \% & \mathrm{f}_{\mathrm{c}}\left(\mathrm{P}_{\mathrm{c}}\right)=1.04 . .1 .98 \\
\mathrm{f}_{\mathrm{p}}\left(\mathrm{P}_{\mathrm{c}}\right)=61 . .64 & \mathrm{I}_{\mathrm{c}}\left(\mathrm{P}_{\mathrm{c}}\right)=2.45 \cdot 10^{-4} . .7 .8 \cdot 10^{-4} \\
\mathrm{E}_{\mathrm{p}}\left(\mathrm{P}_{\mathrm{c}}\right)=7 . .1369 & \mathrm{f}_{\mathrm{b}}\left(\mathrm{P}_{\mathrm{c}}\right)=0.235 . .0 .9 \\
\varepsilon_{\mathrm{r}}\left(\mathrm{P}_{\mathrm{c}}\right)=350 . .507 & \mathrm{I}_{\mathrm{b}}\left(\mathrm{P}_{\mathrm{c}}\right)=1.9 \cdot 10^{-3} . .3 .2 \cdot 10^{-2} \\
\varepsilon\left(\mathrm{P}_{\mathrm{c}}\right)=10 . .301 & \mathrm{Kg}_{15}\left(\mathrm{P}_{\mathrm{c}}\right)=7.1 . .31 \\
\mathrm{H}_{\mathrm{A}}\left(\mathrm{P}_{\mathrm{c}}\right)=87 . .99 & \mathrm{Kg}_{30}\left(\mathrm{P}_{\mathrm{c}}\right)=11.5 . .38 \\
\mathrm{~T}_{\mathrm{p}}\left(\mathrm{P}_{\mathrm{c}}\right)=32 . .215 & \mathrm{Kg}_{45}\left(\mathrm{P}_{\mathrm{c}}\right)=1.6 . .32 .9 \\
\mathrm{C}_{\mathrm{k}}\left(\mathrm{P}_{\mathrm{c}}\right)=0 . .7 .4 & \mathrm{Kg}_{60}\left(\mathrm{P}_{\mathrm{c}}\right)=-1.9 . .22 \\
& \mathrm{Kg}_{90}\left(\mathrm{P}_{\mathrm{c}}\right)=-3.4 . .6 .4
\end{array}
$$

There are a few ways to use these equations on practice. One of the most important is the task of finding the best combination of material properties and structure from the standpoint of a given parameter, which would reflect the quality of the composition. 
In the simplest case, it is possible to set the content of the hard blocks $P_{c}$ or other characteristic of the BPU and calculate all the other characteristics. However, in practice, as a rule, firstly, the exact value of this target parameter is not always known, and secondly, it is often necessary to obtain a BPU with whole set of specified properties. In this case, it is necessary to use weight coefficients for each parameter.

There are simple examples of using weights to obtain a material with preset properties.

Let's introduce the quality index of the material Q, which is an integrated assessment of a given set of characteristics.

It should be noted that for adequate usage of Q all functions must be reduced to same interval of variation, for example to $0 \ldots 1$, otherwise the influence of some functions will prevail over others. The sign «-» in front of one of the parameters indicates that its growth leads to a decrease in the quality of the material. For example, the greater value of the wear intensity $I_{c}$, the worse quality of the material is, accordingly, the lower the value of the parameter Q is obtained. Such parameters are shown in expressions (4):

$$
\begin{aligned}
& \mathrm{Q}\left(\mathrm{P}_{\mathrm{c}}\right)=\mathrm{Q}_{\mathrm{fm}}\left(\mathrm{P}_{\mathrm{c}}\right)+\mathrm{Q}_{\mathrm{fr}}\left(\mathrm{P}_{\mathrm{c}}\right)+\mathrm{Q}_{\mathrm{ab}}\left(\mathrm{P}_{\mathrm{c}}\right) ; \\
& \mathrm{Q}_{\mathrm{fm}}\left(\mathrm{P}_{\mathrm{c}}\right)=\mathrm{f}_{\mathrm{r}}\left(\mathrm{P}_{\mathrm{c}}\right)+\mathrm{E}_{\mathrm{p}}\left(\mathrm{P}_{\mathrm{c}}\right)+\varepsilon_{\mathrm{p}}\left(\mathrm{P}_{\mathrm{c}}\right)+ \\
& +\varepsilon\left(\mathrm{P}_{\mathrm{c}}\right)+\mathrm{H}_{\mathrm{A}}\left(\mathrm{P}_{\mathrm{c}}\right)+\mathrm{T}_{\mathrm{p}}\left(\mathrm{P}_{\mathrm{c}}\right)+\mathrm{C}_{\mathrm{k}}\left(\mathrm{P}_{\mathrm{c}}\right) ; \\
& \mathrm{Q}_{\mathrm{fr}}\left(\mathrm{P}_{\mathrm{c}}\right)=-\mathrm{f}_{\mathrm{c}}\left(\mathrm{P}_{\mathrm{c}}\right)-\mathrm{I}_{\mathrm{c}}\left(\mathrm{P}_{\mathrm{c}}\right)-\mathrm{f}_{\mathrm{b}}\left(\mathrm{P}_{\mathrm{c}}\right)-\mathrm{I}_{\mathrm{b}}\left(\mathrm{P}_{\mathrm{c}}\right) ; \\
& \mathrm{Q}_{\mathrm{ab}}\left(\mathrm{P}_{\mathrm{c}}\right)=-\mathrm{Kg}_{15}\left(\mathrm{P}_{\mathrm{c}}\right)-\mathrm{Kg}_{30}\left(\mathrm{P}_{\mathrm{c}}\right)-\mathrm{Kg}_{45}\left(\mathrm{P}_{\mathrm{c}}\right)- \\
& -\mathrm{Kg}_{60}\left(\mathrm{P}_{\mathrm{c}}\right)-\mathrm{Kg}_{90}\left(\mathrm{P}_{\mathrm{c}}\right) ; \\
& \mathrm{q}\left(\mathrm{P}_{\mathrm{c}}\right)=-\mathrm{I}_{\mathrm{c}}\left(\mathrm{P}_{\mathrm{c}}\right)-\mathrm{H}_{\mathrm{A}}\left(\mathrm{P}_{\mathrm{c}}\right),
\end{aligned}
$$

where $\mathrm{Q}$ is the integrated quality parameter; $\mathrm{Q}_{\mathrm{fm}}$ is the quality parameter which takes into account only the physical and mechanical characteristics; $Q_{\mathrm{fr}}$ is the quality parameter which takes into account only the tribological characteristics; $\mathrm{Q}_{\mathrm{ab}}$ is the quality parameter which takes into account only the characteristics of abrasive wear; and q is the quality parameter that takes into account only the intensity of wear during friction without lubrication and hardness, but preferably hardness.

Now it is possible to find the maximum values of quality parameters by traditional methods of finding extremum, then determine corresponding values of $P_{c}$, and finally the values of all other characteristics. Figure 3 shows not only the points of quality maximum but also the graphs of quality parameters in the entire range of $P_{c}$.

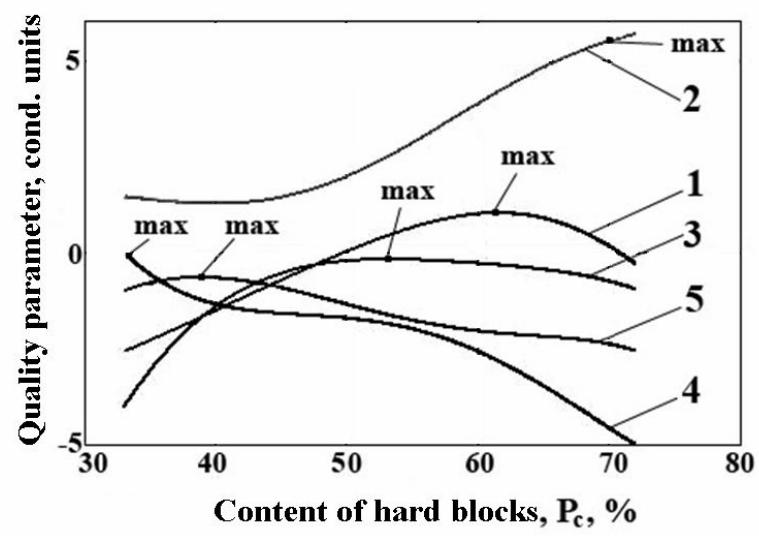

Fig. 3. Graphic dependences of quality parameters on the parameter of morphological structure $\mathrm{P}_{\mathrm{c}}$ of BPU based on OBGA $_{500}: 1-Q$ vs. $P_{c} ; 2-Q_{\text {fm }}$ vs. $P_{c} ; 3-Q_{f}$ vs. $P_{c}$; $4-Q_{a b}$ vs. $P_{c} ; 5-$ q vs. $P_{c}$

Figure 3 clearly shows that the maximum values of quality parameters, depending on the operating conditions, correspond to different contents of rigid blocks $\mathrm{P}_{\mathrm{c}}$, and, consequently, to the different molecular structure of the studied polyurethanes. Thus, for operating conditions where it is necessary to provide a high complex of strength characteristics, it is reasonable to use BPU based on OBGA ${ }_{500}$ with the maximum maintenance of hard blocks $\left(\mathrm{P}_{\mathrm{c}}>60 \%\right)$. For usage as wear-resistant materials, the synthesis of polyurethanes with the formation of cluster of hard blocks in the range of $45-55 \%$ is recommended.

The proposed approach can become a scientific basis for the development of a branded range of linear block-copolyurethanes.

\section{Conclusions}

1. It was established that the development of recommendations for a reasonable choice of linear block-copolyurethanes is mainly intuitive.

2. It was proposed to assess the relationship between structure and properties of investigated materials using quality parameters.

3. By using polyurethane block-copolymers of regular structure based on $\mathrm{OBGA}_{500}$ as an example, a mathematical model has been developed that clearly describes the relationship between the morphological parameter of the structural organization $\mathrm{P}_{c}$ and strength, deformation, thermophysical and tribological characteristics.

4. The obtained dependences allow predicting the behavior of the investigated BPU under different operating conditions, taking into account the quality parameters of the material. 


\section{REFERENCES}

1. Zonnenshteyn M.F. Poliuretany. Sostav, svoistva, proizvodstvo, primenenie. - St. Petersburg: TsOP Professiya, 2018. $-576 \mathrm{p}$.

2. Shtompel V.I., Kercha Yu.Yu. Struktura liniynykh poliuretaniv. - K: Naukova Dumka, 2008. - 247 p.

3. Danil'chenko D.O., Horol's'kij M.S., Danil'chenko O.P. Oglyad fizyko-mekhanichnykh vlastyvostei poliuretanovykh elastomeriv i perspektyvnykh galuzei yih vykorystannya // Khimichna Promyslovist' Ukrayny. - 2001. - No. 3. - P.56-58.

4. Skakun Yu.V., Nizel's'kij Yu.M. Termoplastychni poliuretany: budova, vlastyvosti, vykoristannya // Polimernyi Zhurnal. - 2007. - Vol.29. - No. 1. - P.3-9.

5. Anisimov V.N., Anisimov V.V. Technological features of processing linear block-polyurethanes of different morphology / / Voprosy Khimii i Khimicheskoi Tekhnologii. - 2019. - No. 4. - P.5-11.

6. Anisimov V.N., Anisimov V.V. Linear block-polyurethanes with optimal molecular topology for tribotechnology // Voprosy Khimii i Khimicheskoi Tekhnologii. - 2020. - No. 3. - P.20-25.

7. Sovershenstvovanie metodov issledovaniya fizikokhimicheskikh svoistv polimernykh materialov i zashchitnykh pokrytii / Tishchenko G.P., Kurachenkov V.N., Anisimov V.N., Trofiniovich A.N., Kizhaev S.A. - M.: NIITEKhIM, 1985. 12/242. $-36 \mathrm{p}$.

Received 12.02.2021

\section{ПРОГНОЗУВАННЯ ВЛАСТИВОСТЕЙ ЛІНІЙНИХ БЛОК-КОПОЛІУРЕТАНІВ НА ОСНОВІ ОЛІГОЕСТЕРІВ ІЗ РЕГУЛЯРНОЮ БУДОВОЮ}

\section{В.М. Анісімов, В.В. Анісімов}

Показано, що розробка рекомендацій щодо обгрунтованого вибору лінійних блок-кополіуретанів, які є оптимальними для певних умов експлуатації, є переважно інтуїтивною та не враховує особливостей молекулярної структури та природи вихідних компонентів. Розроблено науково обгрунтований підхід до створення лінійних блок-кополіуретанів із підвищеною зносостійкістю відносно міцності, деформації, теплофізичних і триботехнічних характеристик. Для спрощення аналізу властивостей досліджуваних матеріалів була розроблена математична модель, яка описує взаємозв'язок між усіма надаими властивостями матеріалів та їх структурою. Запропоновано оцінювати взаємозв'язок між структурою та властивостями досліджуваних матеріалів за допомогою параметрів якості. Показано, що максимальні значення параметрів якості залежно від умов експлуатації відповідають різному вмісту твердих блоків $\mathrm{P}_{\mathrm{c}}$, а отже, різній молекулярній структурі досліджуваних поліуретанів. Тому для умов експлуатації, де необхідно забезпечити високий комплекс міцнісних характеристик, раціонально використовувати блок-кополіуретанів на основі $\mathrm{OBGA}_{500} 3$ максимальним вмістом твердих блоків $\left(\mathrm{P}_{\mathrm{c}}>60 \%\right)$. Для використання як зносостійких матеріалів рекомендуються поліуретани, синтезовані з утворенням скупчення твердих блоків в межах $45-55 \%$.
Ключові слова: лінійний блок-кополіуретан, олігоестер, фізико-механічні характеристики, інтенсивність зношування, показник якості матеріалу.

\section{FORECASTING THE PROPERTIES OF LINEAR BLOCK- COPOLIURETHANES BASED ON OLIGOESTERS OF REGULAR STRUCTURE}

V.N. Anisimov, V.V. Anisimov *

Ukrainian State University of Chemical Technology, Dnipro, Ukraine

* e-mail: wwwovilon@gmail.com

We showed that the development of recommendations for a reasonable choice of linear block copolyurethanes that would be optimal for given operating conditions is still intuitive and does not consider the features of the molecular structure and the nature of initial components. We suggested a new scientifically grounded approach to the creation of linear block-copolyurethanes with increased wear resistance in relation to strength, deformation, thermophysical and tribotechnical characteristics. To simplify analysis of the properties of the studied materials, a mathematical model was developed, which describes the relationship between all considered properties of materials and their structure. We proposed to assess the relationship between structure and properties of the investigated materials by using quality indexes. Maximum values of quality indexes, depending on the operating conditions, correspond to different contents of hard blocks $\left(\mathrm{P}_{\mathrm{c}}\right)$, and, consequently, to different molecular structure of the studied polyurethanes. Thus, it is reasonable to use block-copolyurethanes based on $\mathrm{OBGA}_{500}$ with a maximum content of hard blocks $\left(\mathrm{P}_{\mathrm{c}}>60 \%\right)$ for operating conditions where it is necessary to provide high strength characteristics. Polyurethanes synthesized with the formation of clusters of hard blocks in the range of $45-55 \%$ are recommended for the use as wear-resistant materials.

Keywords: linear block-copolyurethane; oligoester; physical and mechanical characteristics; wear intensity; material quality index.

\section{REFERENCES}

1. Zonnenshteyn MF. Poliuretany. Sostav, svoistva, proizvodstvo, primenenie [Polyurethanes: composition, properties, fabrication and usage]. St. Petersburg: TsOP Professiya; 2018. 576 p. (in Russian).

2. Shtompel VI, Kercha YuYu. Struktura liniinykh poliuretaniv [Structure of linear polyurethanes]. Kyiv: Naukova Dumka; 2008. 247 p. (in Ukrainian).

3. Danil'chenko DO, Horol's'kij MS, Danil'chenko OP. Oglyad fizyko-mekhanichnykh vlastyvostei poliuretanovykh elastomeriv i perspektyvnykh galuzey yikh vykorystannya [Review on physical-mechanical properties of polyurethane elastomers and promising areas of their usage]. Khimichna Promyslovist' Ukrayiny. 2001; (3): 56-58.

4. Skakun YuV, Nizel's'kij YuM. Termoplastychni poliuretany: budova, vlastyvosti, vykoristannya [Thermoplastic polyurethanes: structure, properties, and usage]. Polimernyi Zhurnal. 2007; 29(1): 3-9.

5. Anisimov VN, Anisimov VV. Technological features of processing linear block-polyurethanes of different morphology. Voprosy Khimii i Khimicheskoi Tekhnologii. 2019; (4): 5-11. doi: 10.32434/0321-4095-2019-125-4-5-11. 
6. Anisimov VN, Anisimov VV. Linear block-polyurethanes with optimal molecular topology for tribotechnology. Voprosy Khimii i Khimicheskoi Tekhnologii. 2020; (3): 20-25.

doi: 10.32434/0321-4095-2020-130-3-20-25.

7. Tishchenko GP, Kurachenkov VN, Anisimov VN, Trofiniovich AN, Kizhaev SA. Sovershenstvovanie metodov issledovaniya fiziko-khimicheskikh svoistv polimernykh materialov $i$ zashchitnykh pokrytii [Improvement of the methods of researches of physicochemical properties of polymer materials and protective coating]. Moscow: NIITEKhIM; 1985. 12/242. 36 p. (in Russian). 